\title{
Spectrophotometric Determination of Chromium in Water, and Pharmaceutical Samples Using 1-Naphthol
}

\author{
K.SUVARDHAN ${ }^{1}$, S. RAMANAIAH ${ }^{2 *}$, K. SURESH KUMAR ${ }^{1}$, D. REKHA ${ }^{1}$, \\ UMAYUR BHAGAN $^{3}$, G. R.K NAIDU ${ }^{4}$, G. KRISHNAMURTHY NAIDU ${ }^{5}$, \\ B.S. SASTRY ${ }^{6}$, P.CHIRANJEEVI ${ }^{1}$
}

\footnotetext{
${ }^{1}$ Environmental Monitoring Laboratory, Department of Chemistry, S.V University, Tirupati-517502,

$2^{2 *}$ Department of Geology, S.V.University, Tirupati-517502, A.P.,India.

${ }^{3}$ Hindu College, M.S University, Nagarkoal, Tamil Nadu, India.

${ }^{4}$ Department of Environmental Sciences, S.V University, Tirupati-517502, A.P., India.

${ }^{5}$ Department of Pharmacy, S.V. Govt. Polytechnic, Tirupati-517501.A.P., India

${ }^{6}$ Department of Pharmaceutical Sciences, Andhra Univeristy,Vishakapatnam-530003. A.P., India
}

Received 8 November 2004; Accepted 14 December 2004

\begin{abstract}
Facile and sensitive spectrophotometric methods for the determination of trace and ultra trace amounts of chromium (VI) are described. 4-aminoantipyrine (APP) reacts with 1-naphthol (NPL) in presence of oxidising agent potassium dichromate in acidic medium to produce red coloured product having $\lambda_{\max }$ of $485 \mathrm{~nm}$. The molar absorptivity and Sandell's sensitivity were $2.07 \times 10^{4} 1 \mathrm{~mol}^{-1} \mathrm{~cm}^{-1}$ and $0.00240 \mu \mathrm{g} / \mathrm{cm}^{2}$ respectively. The colour is stable for more than $6 \mathrm{~h}$. The system obeys Beer's law in the range, 2-18 $\mu \mathrm{g}$ for determination of chromium (VI). The detection limits of chromium (VI) is $0.048 \mu \mathrm{g} \mathrm{ml}^{-1}$. The method is highly reproducible and has been applied to the analysis of chromium in synthetic, natural water samples and pharmaceutical preparations and the results compared favourably with the reported method.
\end{abstract}

Key words Spectrophotometric determinations, Pharmaceutical samples, 1-naphthol

\section{Introduction}

The determination of trace amounts of chromium in soils and other naturally occurring materials is of considerable interest, because of the contrasting biological effects of its two common oxidation states, chromium (III) and chromium (VI) and also the growing interest in environmental problems. It is known that an increase in the concentration of chromium in soils makes them infertile and that the toxic effect depends to some extent on the chromium Oxidation State. On the other hand, the introduction of chromium salts into soils has some positive effects due to activation of some biochemical processes ${ }^{1}$. Chromium (III) is an essential nutrient for maintaining normal physiological 
function ${ }^{2}$, whereas chromium(VI) is toxic ${ }^{3}$. The determination of chromium by spectrophotometric methods based on oxidation of organic compounds $^{4-6}$ and on formation ion associates ${ }^{1,7}$ has the disadvantage of a high blank value. The most widely used reagent for chromium (VI) determination is diphenyl-carbazide ${ }^{8,9}$, but it suffers serious interferences from $\mathrm{Fe}(\mathrm{III}), \mathrm{Mo}(\mathrm{VI}), \mathrm{Cu}(\mathrm{II})$ and $\mathrm{Hg}(\mathrm{II})^{8,10}$ and also the formed complex is stable for only $30 \mathrm{~min}$ in the presence of a phosphate buffer ${ }^{11}$. Other reagents have been suggested for spectrophotometric determination of chromium with the use of 4(2-pyridylazo) resorcinol ${ }^{12}$, phenylarsenazo ${ }^{13}$, and gallacetophenone oxime ${ }^{14}$, citrazinic acid ${ }^{15}$. The above reported methods suffer from several drawbacks like less sensitive, low detection limits, high reagent consumption and instability of resultant product. The determination of trace amounts of chromium is important in studies of biological processes and for industrial purposes. So development of a simple, rapid and sensitive spectrophotometric method is highly desirable.

The aim of the present work is to provide facile, rapid, and sensitive spectrophotometric determination of chromium (VI) in various environmental samples. 4-aminoantipyrine reacts with 1-naphthol in presence of potassium dichromate in acidic medium to form red colored product. Chromium(III) is determined after it is oxidized to chromium(VI) by bromine. The proposed method has been used to determination of chromium in synthetic, natural, water samples and pharmaceutical preparations.

\section{Materials and Methods}

\section{Reagents}

All chemicals used were of analytical grade. Deionised double distilled was used throughout the experiment.

A stock solution of chromium (IV) solution $\left(1000 \mu \mathrm{g} \mathrm{ml}^{-1}\right)$ was prepared by dissolving $0.2829 \mathrm{~g}$ of $\mathrm{K}_{2} \mathrm{Cr}_{2} \mathrm{O}_{7}$ in $100 \mathrm{ml}$ of deionised double distilled water. The stock solution was further diluted as needed. A stock solution of chromium (III) $\left(1000 \mu \mathrm{g} \mathrm{ml}^{-1}\right)$ was prepared by dissolving $0.2829 \mathrm{~g}$ of $\mathrm{K}_{2} \mathrm{Cr}_{2} \mathrm{O}_{7}$ in $50 \mathrm{ml}$ of deionised double distilled water, adding $1 \mathrm{ml}$ of saturated sodium sulphite solution followed by acidifying with $1 \mathrm{ml}$ of $2.5 \mathrm{M}$ sulphuric acid, and then boiling for $2 \mathrm{~min}$ to remove excess $\mathrm{SO}_{2}$ and diluting with water to $100 \mathrm{ml}$. A suitable volume of this solution was diluted to obtain the working standard.

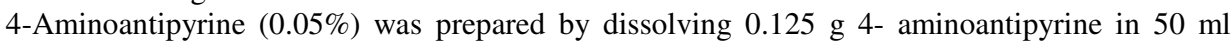
concentration $\mathrm{HCl}$ and diluting to $250 \mathrm{ml}$ with deionised double distilled water. 1-naphthol $(0.1 \%)$ was prepared by dissolving $0.1 \mathrm{~g}$ of 1-naphthol in $2 \mathrm{ml}$ of $4 \mathrm{M} \mathrm{NaOH}$ and diluting to $100 \mathrm{ml}$ with deionised double distilled water.

\section{Others reagents}

The following reagents were prepared by dissolving appropriate amounts of reagents in deionised double distilled water : bromine water (saturated), sulpho salicylic acid (5\%), $\mathrm{KOH}(4 \mathrm{M})$, sulphuric acid (0.5 M and 2.5 M), $\mathrm{HCl}(5 \mathrm{M})$, methyl isobutyl ketone (MIBK) used for the extraction of iron.

\section{Apparatus}

A HITACHI U 2001 spectrophotometers with $1.0 \mathrm{~cm}$ matched quartz cells were used for all absorbance measurements. Elico model Li-129 pH meter with combined glass and calomel electrode was used for $\mathrm{pH}$ measurement.

\section{Procedure}

\section{Determination of chromium(VI)}

An aliquot of a sample solution containing 2-15 $\mu \mathrm{g}$ of chromium(VI) was transferred into a series of $10 \mathrm{ml}$ calibrated flasks. A volume of $0.5 \mathrm{ml}$ of $0.05 \%$-aminoantipyrine and $0.5 \mathrm{ml}$ of $0.1 \%$ of 1 naphthol was added to each flask in presence of oxidising agent, potassium dichromate in acidic medium and the mixture was allowed to stand for $2 \mathrm{~min}$. Then, the contents were diluted to the 
mark with distilled water and mixed well. After $5 \mathrm{~min}$, absorbance of the coloured product was measured at $485 \mathrm{~nm}$ against a reagent blank.

\section{Determination of chromium(III)}

An aliquot of sample solution containing 2-15 $\mu \mathrm{g}$ of chromium(III) was transferred into a series of $10 \mathrm{ml}$ calibrated flasks. A volume of $0.5 \mathrm{ml}$ saturated bromine water and $0.5 \mathrm{ml}$ of $4 \mathrm{M} \mathrm{KOH}$ solution were added to each flask and allowed to stand for $5 \mathrm{~min}$. Then, $0.5 \mathrm{~mL}$ of $2.5 \mathrm{M}$ sulphuric acid and $0.5 \mathrm{~mL}$ of $5 \%$ sulpho salicylic acid were added and the above procedure [chromium(VI)(IPP method)] for diazotisation was followed. The absorbance of each solution at $500 \mathrm{~nm}$ against a reagent blank was recorded.

Analysis of mixture containing chromium(III) and chromium(VI):

An aliquot $(15 \mu \mathrm{g})$ of a mixture is analyzed separately according to the procedures for chromium(VI) and chromium(III). The concentration of chromium (III) was measured as :

$$
\begin{aligned}
& \text { Concentration of }\} \text { Total concentration of Concentration of } \\
& \operatorname{chromium}(\mathrm{III})\}=[\mathrm{Cr}(\mathrm{III})+\mathrm{Cr}(\mathrm{VI})] \quad-\operatorname{Chromium}(\mathrm{VI})
\end{aligned}
$$

\section{Results and Discussion}

4-aminoantipyrine in presence oxidising agent potassium dichromate in acidic medium couples with 1naphthol to form red coloured product of $\lambda_{\max } 485 \mathrm{~nm}$. The absorption spectra of chromium reaction products formed are shown in Figure 1.

Figure 1. The absorption spectra of chromium reaction products

1. Reagent blank

2. $4-A A P+N P L$

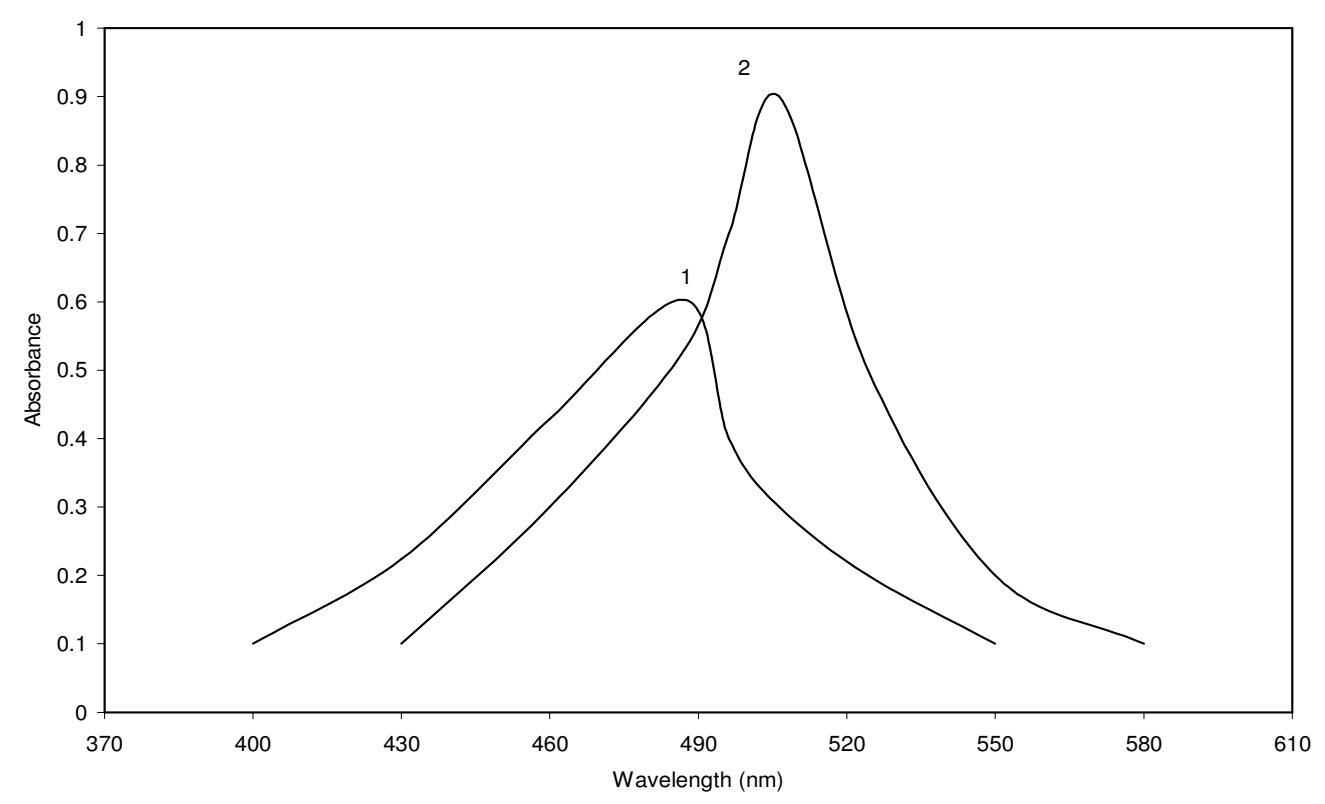




\section{Optimum reagents concentration}

Various concentration and volume ranges for all the reagents were studied. However, the following are the optimum concentration and volume ranges.

$0.2-0.5 \mathrm{ml}$ of $0.05 \%$ 4-aminoantipyrine, $0.3-0.5 \mathrm{ml}$ of $0.1 \%$ 1-naphthol, $1.5-2.2 \mathrm{ml} \mathrm{o} 0.1 \%$ potassium dichromate were required to get maximum colour intensity. In IPP method, the excess of nitrite could be removed by the addition of 5\% sulpho salicylic acid solution. Addition of excess of 5\% sulposalicylic acid solution has no effect on absorbance values.

\section{Choice of oxidizing agent}

Chromium(III) was determined after it was oxidized to chromium(VI), various oxidizing agent ${ }^{16}$ were used : presulfate in the presence of a silver ion as the catalyst in an acid solution, permanganate in an acid medium, and hydrogen perioxide and bromine in an alkaline medium. For all these methods, excess oxidizing agent must be destroyed before the determination of $\mathrm{Cr}(\mathrm{VI})$ to avoid the interference with the determination. usually, excess persulfate and peroxide were removed by boiling, and permanganate was destroyed by adding sodium azide.

\section{Choice of solvent}

Dilution of the resultant coloured solution with different solvents like water, methanol, ethanol, acetic acid and aceto nitrile have been tested. Results showed that water give maximum intenisty and stability of the colour.

\section{Quantification}

Beer's law is obeyed over the chromium concentration range of $2-18 \mu \mathrm{g} \mathrm{ml}^{-1}$. Limit of Quantification (LOQ) is determined by taking the ratio of standard deviation $(\sigma)$ of the blank with respect to water and the slope of calibration curve (s) multiplied by a factor 10 . That means, LOQ is approximately 3.3 times Limit of Detection (LOD). Naturally, the LOQ slightly cross the lower limit of Beer's law range. But, LOD is well below the lower limit of the Beer's law range. The upper limit of the Beer Lambert range is determined by a plot of absorbance against concentration at the value of $\lambda_{\max }$. Beyond this limit, the correlation results were really affected. Hence, the measurements were excluded above these limits to keep the relationship linear. The molar absorptivity, sandell's sensitivity and other optical characteristics and precision data are given in Table1.

Table 1. Optical characteristics and precision data

\begin{tabular}{ll}
\hline Parameters/Characteristics & \\
\hline Colour & Red \\
$\lambda_{\max }$ & 485 \\
Stability & More than $6 \mathrm{~h}$ \\
Beer's law range $\left(\mu \mathrm{g} \mathrm{ml}^{-1}\right)$ & $2-18$ \\
Limit of detection $\left(\mu \mathrm{g} \mathrm{ml}^{-1}\right)$ & 0.048 \\
Limit of Quantification $\left(\mu \mathrm{g} \mathrm{ml}^{-1}\right)$ & 0.9568 \\
Molar absorptivity $\left(1 \mathrm{~mol}^{-1} \mathrm{~cm}^{-1}\right)$ & $2.07 \mathrm{x} 10^{4}$ \\
Sandell's sensitivity $\left(\mu \mathrm{g} \mathrm{cm}^{-2}\right)$ & 0.00240 \\
Regression equation $(\mathrm{Y})^{\mathrm{a}}$ & \\
Slope $(\mathrm{b})$ & 0.04542 \\
Intercept(a) & -0.0016 \\
Correlation co-efficient $(\mathrm{r})^{\mathrm{b}}$ & 0.9936 \\
Range of Error & $\pm 1.9 \%$ \\
${ }_{\mathrm{a}}^{\mathrm{Y}} \mathrm{Y}=\mathrm{bx}+\mathrm{a}$, Where $\mathrm{x}$ is the concentration in $\mu \mathrm{g} / \mathrm{ml}$ \\
${ }_{\mathrm{b}} \mathrm{n}=5$
\end{tabular}




\section{Reaction mechanism}

4- amino antipyrine react with 1- naphthol in presence of oxidising agent, potassium dichromate in acid medium to give a red coloured product with $\lambda_{\max }$ of $485 \mathrm{~nm}$. The reaction mechanisms for the formation of the products are shown in scheme 1.

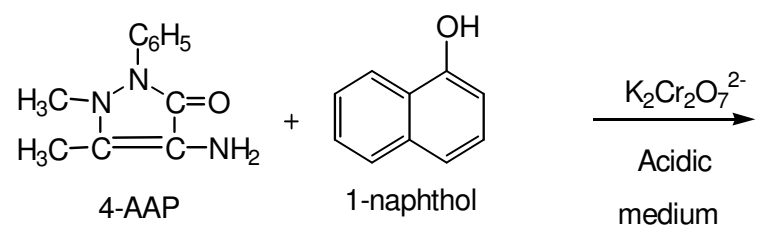<smiles>Cc1c(N=C2C=CC(=O)c3ccccc32)c(=O)n(C(C)(C)C)n1C</smiles>

Scheme 1. Reaction mechanism for the formation of the product.

\section{Stability}

The stability of the red product formed was stable more than $6 \mathrm{~h}$. An increase of temperature from 10$40{ }^{\circ} \mathrm{C}$, did not affect the absorbance in the present study. However, a temperature of $30{ }^{\circ} \mathrm{C}$ is recommended for reproducible results.

\section{Tolerance of non-target species:}

The tolerance of various ions at ppm levels on the determination of chromium(VI) was examined. Tolerance limits of interfering species were established at those concentrations that do not cause more than $\pm 2.0 \%$ error in absorbance values of chromium(VI) at $1 \mathrm{ppm}$ and data was summarized Table 2 . The results indicated that $\mathrm{Cu}(\mathrm{II}), \mathrm{Fe}(\mathrm{III})$, and $\mathrm{Co}$ (II) interfere severely. However, the tolerance level for these ions may be increased by the addition of $1 \mathrm{ml}$ of $1 \%$ EDTA.

\section{Applications}

The proposed method was applied to the quantitative determination of chromium in water and pharmaceutical samples. The results are presented in Table $\mathbf{3}$ and $\mathbf{4}$ respectively.

Analysis in Spiked and Natural water samples:

The proposed method is employed for different natural water samples collected around Tirupati area. The samples were used directly to measure the metal ions by the method after filtered with cellulose membrane of pore size $0.45 \mu \mathrm{m}$. Then spiked water samples were prepared with 31 of deionised distilled water by adding known amount of potassium dichromate and determined by the procedure discussed earlier. Percentage recovery of chromium in natural and spiked water samples are presented in Table 3omium in natural and spiked water samples are presented in Table 3.

Analysis of pharmaceutical samples:

Samples of the finely ground multi vitamin-multi mineral tablets containing chromium(III) were treated with $5 \mathrm{ml}$ of nitric acid, and the mixtures were evaporated to dryness. The residue was leached with $5 \mathrm{ml}$ of $0.5 \mathrm{M} \mathrm{H}_{2} \mathrm{SO}_{4}$. The solution was diluted to a known volume with water. Suitable aliquots of the sample solution were analyzed according to the aforesaid procedure for chromium(III).

Statistical analysis of the results by $F$ and $t$-test showed no significant difference in accuracy and precision of the proposed and reference methods ${ }^{8,19}$. 
Table 2. Tolerance of non-target species on the determination of $1 \mathrm{ppm}$ of $\mathrm{Cr}(\mathrm{VI})$

\begin{tabular}{|c|c|c|c|}
\hline Ion & $\begin{array}{l}\text { Tolerance level } \\
\quad\left(\mu \mathrm{g} \mathrm{ml}^{-1}\right)\end{array}$ & Ion & $\begin{array}{c}\text { Tolerance level } \\
\qquad\left(\mu \mathrm{g} \mathrm{ml}^{-1}\right)\end{array}$ \\
\hline $\mathrm{A} 1^{3+}$ & 500 & $\mathrm{Ce}^{4+}$ & 20 \\
\hline $\mathrm{Ca}^{2+}$ & 20 & $\mathrm{MoO}_{4}^{2-}$ & 1000 \\
\hline $\mathrm{Fe}^{3+}$ & 8 & Citrate & 1500 \\
\hline $\mathrm{Fe}^{2+}$ & 6 & $\mathrm{~F}^{-}$ & 3000 \\
\hline $\mathrm{Na}^{+}$ & 3000 & $\mathrm{CO}_{3}^{2-}$ & 3000 \\
\hline $\mathrm{Co}^{2+}$ & 10 & Tartarate & 2000 \\
\hline $\mathrm{Pb}^{2+}$ & 600 & Sulphite & 3000 \\
\hline $\mathrm{Ni}^{2+}$ & 50 & Oxalate & 2000 \\
\hline $\mathrm{Cu}^{2+}$ & 10 & Sulfate & 3000 \\
\hline $\mathrm{Ag}^{+}$ & 80 & Chloride & 3000 \\
\hline $\mathrm{Mg}^{2+}$ & 2000 & Nitrate & 2000 \\
\hline $\mathrm{Cd}^{2+}$ & 500 & $\mathrm{PO}_{4}^{3-}$ & 2000 \\
\hline $\mathrm{Hg}^{2+}$ & 50 & Acetate & 3000 \\
\hline $\mathrm{Ba}^{2+}$ & 2000 & $\mathrm{AsO}_{3}^{3-}$ & 2000 \\
\hline $\mathrm{Bi}^{3+}$ & 1500 & EDTA & 5000 \\
\hline $\mathrm{Mn}^{2+1}$ & 500 & $\mathrm{IO}_{3}^{-}$ & 2000 \\
\hline
\end{tabular}


Table. 3. Analytical results of chromium determination in water samples around Tirupati.

\begin{tabular}{lcccccccc}
\multicolumn{1}{c}{ Sample } & \multicolumn{3}{c}{ Proposed method } \\
& $\begin{array}{c}\text { Added } \\
\left(\mu \mathrm{g} \mathrm{ml}^{-1}\right)\end{array}$ & $\begin{array}{c}\text { Found } \\
\left(\mu \mathrm{m} \mathrm{m}^{-1}\right)\end{array}$ & $\begin{array}{c}\text { Recovery } \\
(\%)\end{array}$ & $\begin{array}{c}\text { S.D. } \\
(\%, \mathrm{n}=4)\end{array}$ & $\begin{array}{c}\text { Added } \\
\left(\mu \mathrm{g} \mathrm{ml}^{-1}\right)\end{array}$ & $\begin{array}{c}\text { Found } \\
\left(\mu \mathrm{m}^{-1}\right)\end{array}$ & $\begin{array}{c}\text { Recovery } \\
(\%)\end{array}$ & $\begin{array}{c}\text { S.D. } \\
(\%, \mathrm{n}=4)\end{array}$ \\
Synthetic sample-I & 0.30 & 0.295 & 98.3 & 0.621 & 0.3 & 0.292 & 97.3 & 0.770 \\
Synthetic sample-II & 0.50 & 0.493 & 98.6 & 0.730 & 0.5 & 0.490 & 98.0 & 0.665 \\
Natural water sample-I & - & 0.67 & - & - & - & 0.61 & - & - \\
& 0.60 & 1.26 & 99.3 & 0.716 & 1.20 & 1.799 & 99.0 & 0.917 \\
Natural water sample-II & - & 0.91 & - & - & - & 0.98 & - & - \\
& 1.20 & 2.1 & 99.1 & 0.716 & 2.40 & 3.34 & 98.7 & 0.770
\end{tabular}


Table. 4. Determination of chromium in pharmaceutical preparations $(n=5 ; p=0.95)$

\begin{tabular}{|c|c|c|c|c|c|}
\hline Sample (w/v) & Composition of tablet (w/tablet) & $\begin{array}{l}\text { Certified value of } \\
\text { chromium, } \\
\text { mg/tablet }\end{array}$ & $\begin{array}{l}\text { Chromium } \\
\text { found, } \mathrm{mg}^{\mathrm{a}} \\
\quad / \text { tablet }\end{array}$ & Recovery $(\%)$ & t-test ${ }^{b}$ \\
\hline $\begin{array}{l}\text { Optisulin [Sai Mira } \\
\text { Innopharm Pvt. Ltd., Inida] } \\
(0.3 \mathrm{~g} / 100 \mathrm{ml})\end{array}$ & $\begin{array}{l}\text { Zinc sulphate monohydrete, } 27.50 \mathrm{mg} \text {, vitamin } \\
\mathrm{B}_{6}, 3 \mathrm{mg} \text {; vitamin } \mathrm{B}_{12}, 15 \mathrm{mg} \text {; folic acid, } 1 \mathrm{mg} \text {; } \\
(0.3 \mathrm{~g})\end{array}$ & 0.500 & $0.497 " 0.008$ & 99.40 & 1.13 \\
\hline $\begin{array}{l}\text { Chromoplex[Aristo } \\
\text { Pharmaceuticals Ltd., } \\
\text { India] }(0.550 \mathrm{~g} / 100 \mathrm{ml})\end{array}$ & $\begin{array}{l}\text { Zince sulphate monhydrate, } 27.50 \mathrm{mg} \text {; vitamin } \\
\mathrm{B}_{1}, 10 \mathrm{mg} \text {; vitamin } \mathrm{B}_{12}, 15 \mathrm{mg} \text {; nicotinamide, } \\
50 \mathrm{mg} \text {; calcium pantothenate, } 12 \mathrm{mg} \text {; folic acid, } \\
1 \mathrm{mg} \text {; vitamin } \mathrm{C}, 150 \mathrm{mg} ;(0.550 \mathrm{~g})\end{array}$ & 0.200 & $0.199 " 0.003$ & 99.50 & 1.12 \\
\hline $\begin{array}{l}\text { Fourts B[Fourts } \\
\text { Laboratories Pvt. Ltd., } \\
\text { India] }(0.65 \mathrm{~g} / 100 \mathrm{ml})\end{array}$ & $\begin{array}{l}\text { Thiamine mononitrate, } 10 \mathrm{mg} \text {; riboflavin, } 10 \\
\text { mg; pyrodoxine hydrochloride, } 3 \mathrm{mg} \text {; } \\
\text { niacinamide, } 50 \mathrm{mg} \text {; vitamin } \mathrm{C}, 150 \mathrm{mg} \text {; zinc } \\
\text { sulphate, } 80 \mathrm{mg} \text {; selenium, } 100 \mu \mathrm{g} ;(0.65 \mathrm{~g})\end{array}$ & 0.150 & $0.149 " 0.005$ & 99.90 & 0.45 \\
\hline
\end{tabular}

a Mean" stndard deviation $(n=5)$.

b Tabulated t-value for 4 degrees of freedom at $P(0.95)$ is 2.776 . 


\section{Conclusion}

The proposed method for determining chromium (VI) is simple, rapid, sensitive, and has a wide analytical range without the need for extraction or heating. The developed method does not involve any special reaction conditions and offers the advantages of high colour stability when compared to the standard diphenylcarbazide method. The method has the added advantage of determining individual amounts of $\mathrm{Cr}$ (VI) and $\mathrm{Cr}(\mathrm{III})$. The proposed method has been successfully applied to the determination of trace amounts in water and pharmaceutical preparation.

\section{References}

1. Kamburova M, Talanta 1993, 40, 713.

2. Versiek J and Cornelis R, Ana. Chi Act, 1980, 116, 217.

3. Eckert J M, Judd R J, Lay P A and Symons A D, Anal Chim Acta, 1991, 255, 31.

4. Buscarons Artivas, J Anal Chim Acta, 1957,16, 452.

5. Jacobsen. E and Lan.W, Anal Chim Acta, 1966,36, 135.

6. Raj J B and Gowda H S, Analyst (Cambridge, U.K.), 1995, 120, 1815.

7. Kamburova M, Talanta, 1993, 40, 707.

8. Luke C L, Anal Chem, 1958, 30, 2050.

9. Marchart H, Anal Chim Acta, 1964, 30, 11.

10. Urone.P G, Anal Chem, 1952, 24,1355.

11. Saltzman B E, Anal Chem., 1952, 24, 1016.

12. Nagarkar S G and Eshwar M C, Indian J Technol, 1975, 377.

13. Sun, Fu.-Sh, Talanta, 1983, 30, 446.

14. Rao P N and Reddy K A, J. Indian Chem Sco, 1980, 57, 402.

15. Revanasiddappa H D and Kiran Kumar, J Anal Chem, 2001 56(12).

16. Upadhyay S and Gupta V K, J Indian Chem Soc, 1986, 63, 769. 


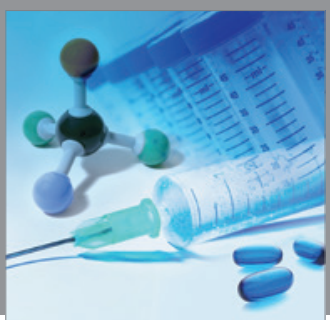

International Journal of

Medicinal Chemistry

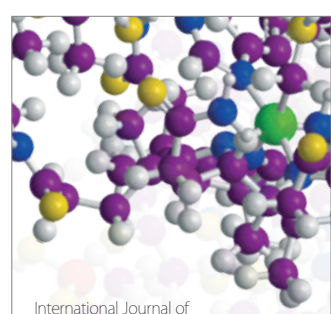

Carbohydrate Chemistry

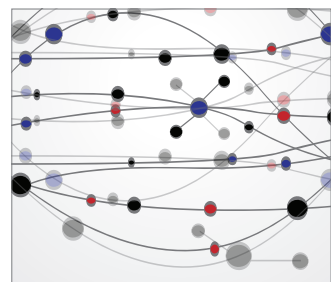

The Scientific World Journal
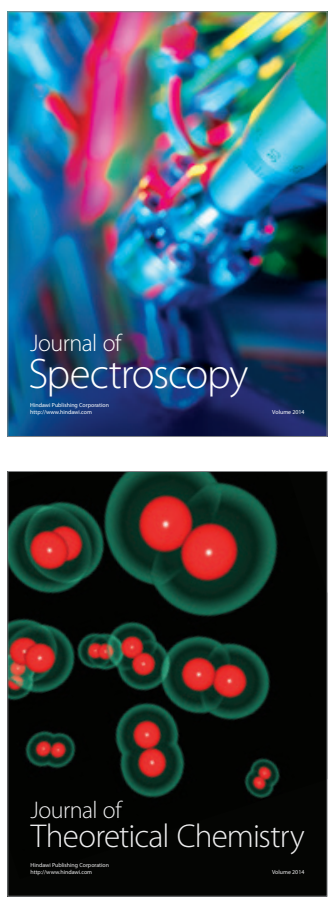
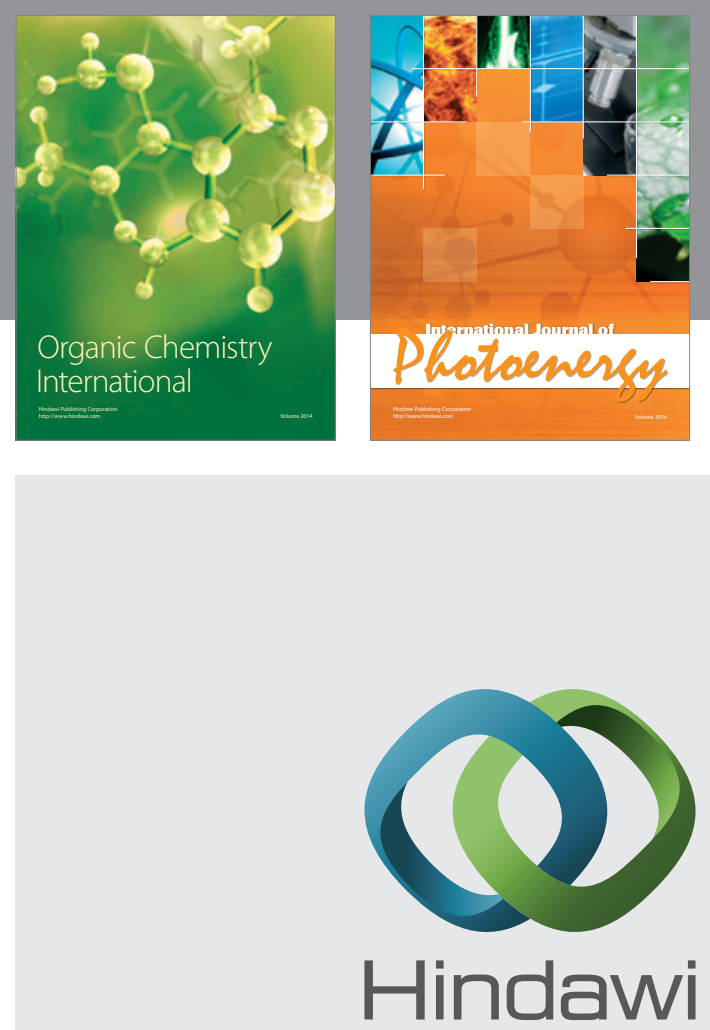

Submit your manuscripts at

http://www.hindawi.com
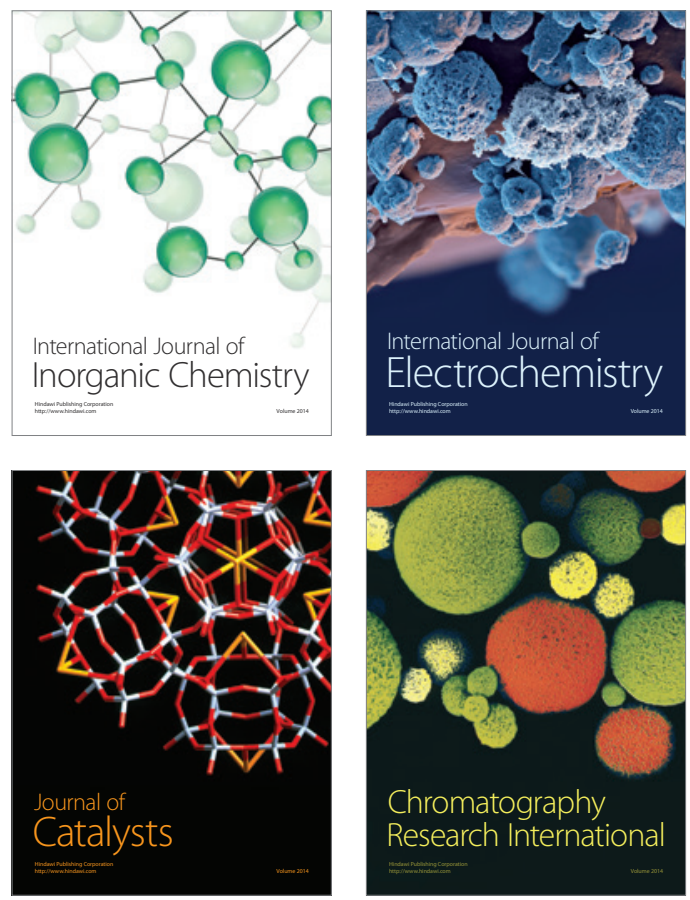
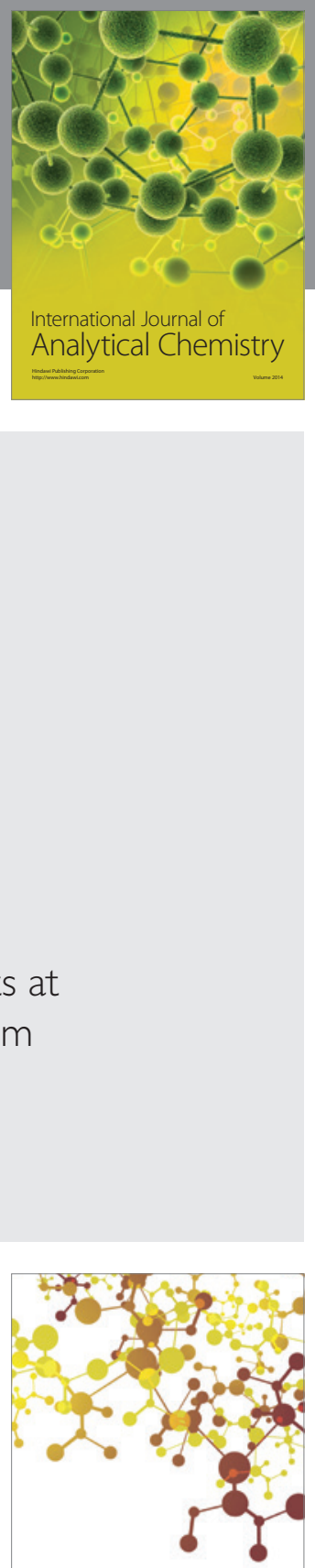

Journal of

Applied Chemistry
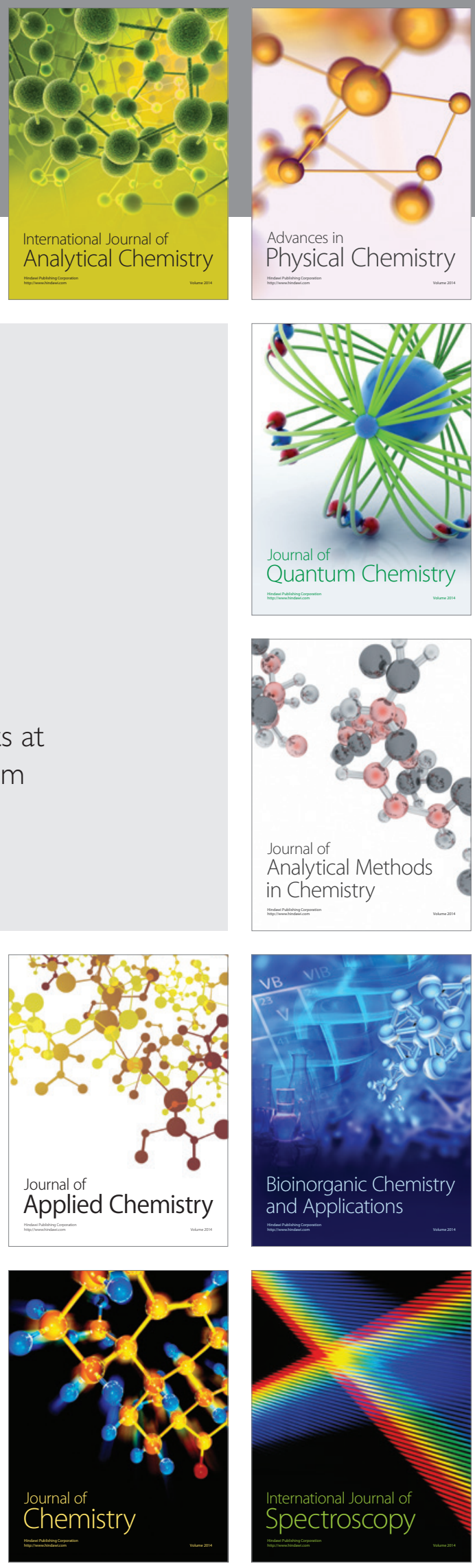